\title{
A Proposal for an Integrative Model of Academic Innovativeness: The Case of Business Schools in the Kingdom of Saudi Arabia
}

\author{
Dr. Wided Ragmoun (Corresponding author) \\ Business Administration, CBE - Qassim University, Saudi Arabia \\ Tel: 00966535773379 \\ E-mail: Wided.ragmoun@yahoo.fr \\ Dr. Abdullah Abdulmohsen Alfalih \\ Business Administration, CBE - Qassim University, Saudi Arabia \\ Tel: 00966555127773 \\ E-mail: faleh-6@hotmail.com
}

Dr. Abdulaziz Abdulmohsen Alfalih
Business Administration, CBE - Qassim University, Saudi Arabia

Tel: 00966555123660

E-mail: aziz-al-faleh@hotmail.com

Received: Oct. 5, 2017 Accepted: Oct. 27, 2017 Online published: Nov. 1, 2017

doi:10.5296/ijhrs.v8i1.11953 URL: https://doi.org/10.5296/ijhrs.v8i1.11953

\begin{abstract}
Based on previous research related to innovation at different levels, this paper will try to define an integrative model of academic innovation. In other words, we will propose a model which includes antecedents, dimensions and outcomes of academic innovation in business schools in the Kingdom of Saudi Arabia (KSA).

This research is based on 140 questionnaires from different business schools in KSA. In this case, our objective is not only exploratory. We can say that this research must provide us with
\end{abstract}


an integrative model of academic innovativeness, but this concept seems to be an objective and a variable here.

It is an objective because we are looking to explain its determinants based on organizational learning capacity. At the same time, if this innovativeness exists and is defined in business schools, what is its importance and its tangible effect? For this, we must consider innovativeness as a moderator variable with different dimensions, which can improve academic performance in both teaching and research.

This study shows that creativity and the need for collaboration are considered to be specific attributes of innovativeness in this field, and academic performance is one of the major outcomes of this dynamic process of innovation, appreciated at two levels: individual and organizational.

Keywords: academic innovation, academic performance, integrative model, organizational learning capacity

\section{Introduction}

The basic objective of this research is to discover and explore academic innovativeness across an integrative model of its antecedents, determinants and outcomes, because this construct is considered a crucial notion for every organization (Wang and Ahmed, 2004). In other words, whatever the field of activity, innovation is important for survival and prosperity; especially for education, which has to deal with an important social dilemma and economic facts (Lauder et al., 2006).

In general, innovation can be defined as "the implementation of a new or significantly improved product (good or service), or process, a new marketing method, or a new organizational method in business practices, workplace organization or external relations" (Oslo Manuel, 2005).

According to our literature review, the difficulty of measuring innovation (Lam, 2005) complicates its implementation. Here, innovation is considered a final output of the innovation process, based on many other elements which can be more important than innovation, because they determine its possibility to occur. Our point of view considers that the availability of some factors is enough to automatically generate innovation such as innovativeness, which is defined as a fundamental propensity to innovate; there is "cause (innovation) and effect (quality and effectiveness)" (Nabi and al., 2017, p.23). We are therefore looking for innovativeness (not innovation), especially academic innovativeness. The objective here is to define this approach of innovation in the academic field and to identify its components. The theoretical framework developed here can become a user's guide for academics to innovate.

The literature review related to academic innovativeness is very limited. To define this concept, we have to define innovativeness in general, then present organizational innovativeness, and finally discuss the specificity of this innovativeness in education as a special field of research in this study. 
Dealing with innovativeness, its importance and its determinants requires a theoretical review of innovation that refers to the generation or adoption of new ideas and behaviors (which can be a new product, service, technology, operation, procedure or a new strategy) (Liao et al., 2008). Here we have to identify academic innovativeness, its antecedents represented by organizational learning capacities (OLC) and its outcomes appreciated by academic performance (teaching and research).

Then, we will try to verify the importance of academic innovativeness such as a moderator variable between its antecedents and outcomes.

Three parts will be presented in order to clarify concepts and relationships.

\section{Academic Innovativeness}

To develop a definition of this construct, we have to first define innovation, then innovativeness, in order to identify how this construct can be related to the academic field, and how it can serve it according to the education sector's different specifics.

In fact, contrary to a popular idea that education is a sector not prone to innovation and change (Cerna, 2013), recent research by the Centre for Educational Research and Innovation shows that "education systems are much more complex [...] And many innovations are happening at the frontline of the system, in schools and classrooms, with pioneering teachers and inventive school leaders creating innovative learning environments" (Oslo Manuel, 2005, p32).

In other words, we must redefine innovation and innovativeness through the lens of the education system, represented by teachers and schools. But we must remember that education must integrate change and social needs. Additionally, this sector has a double role in society, because it must innovate as an organization and also adopt teaching, learning and organizational practices related to skills for innovation (Winner et al., 2013).

According to Cross and Cross (1998) innovation as an object includes some important components:

Novelty: related to the nature of innovation

Phenomenon of change: innovation means change in order to accept the new situation

Finalized action: innovations are reflected by a new product or by the improvement of certain methods.

Process: innovation is above process, with its stages.

So, innovation is a voluntary action which stems from a desire to change rather than a need to respond to a difficulty.

"Innovation resembles mutation, the biological process that keeps species evolving so they can better compete for survival" (Hoffman and Holzhuter, 2012, p.3). It also means "[...] the successful introduction of a new thing or method" (Brewer and Tierney, 2012, p.15). In essence, "[...] innovation seems to have two subcomponents. First, there is the idea or item 
which is novel to a particular individual or group and, second, there is the change which results from the adoption of the object or idea" (Evans and Leppman, 1970, p.16).

Based on this, innovation seems to be a positive change which is very important to maintain.

Like any human activity, education must innovate to improve students' level of education and educational outcomes (Vieluf et al., 2012).

Thus, academic innovation must be a process with important traits such a response to change, the necessity of a better situation and voluntary action. This is evidenced by the state of continuous change in which we are living. But is this process the same as the innovation process adopted by other organizations?

We can hypothesize that this process is different because, as detailed in the first part of this research, the education sector must innovate and stimulate innovation through the generation of innovation skills.

The Stanford Research Institute presents academic innovation as a necessity to meet the "'school of the future" and the contemporary world (Vieluf et al., 2012), based on the creativity discovery and the ability to develop a creative idea (Csikszentmihalyi, 2013) of teachers and groups.

It can relate to actors, techniques, organizations or context (Charlier and Peraya, 2003), and affect "educational system: theory and practice, curriculum, teaching and learning, policy, technology, institutions and administration, institutional culture, and teacher education. It can be applied in any aspect that can make a positive impact on learning and learners" (Serdyukov, 2017, p 415) and which emphasizes the change process much more than its product (Cross and Cross, 1998).

Process, levels and actors seem to be invariants of academic innovation and as a process it needs an input, an output and transformation activities. In this way, innovativeness can be considered a particular form of behavior (input) that drives innovation activity and produces dynamic capabilities able to enhance the development of innovations (output) (Serdyukov, 2017).

Here, we are looking for innovativeness considered as a multidimensional concept; it represents the strategic and competitive orientation of an organization providing a vivid mental vision of an output (Manu, 1992). It is the precursor to innovation and represents a firm`s ability to innovate (Wang and Ahmed, 2004).

Hult et al. (2004) consider it the capacity to introduce new processes, products or ideas; it is an organization`s intention to be innovative (Kundu and Katz, 2003).

Furthermore, innovativeness can be divided into two dimensions: technological and behavioral. The first is the technological capacity to innovate, and the second supposes a willingness and commitment to innovate (Avlonitis et al., 1994).

As a result of this brief theoretical analysis, academic innovativeness - the object of this study - is defined as the capacity of actors to stimulate innovation and to develop a positive 


\section{Macrothink}

International Journal of Human Resource Studies

ISSN 2162-3058

2018, Vol. 8, No. 1

perception of innovation in the educational sector. It can be technological and behavioral.

This definition will be refined at the end of the research. In fact, the definition of academic innovativeness is one of our theoretical objectives. The dimensions of the innovativeness concept still lack clarity (Ellonen et al., 2008), and the concept of academic innovativeness is almost absent from the literature.

The conceptual framework, presented below, is based on three elements: antecedent, determinants and outputs, through which we will be able to identify the composition of academic innovativeness.

The definition of these components is related to the concept of the Innovative Learning Environment (ILE). The rest of the paper will be devoted to the ILE framework. Elements related to academic innovativeness will be deduced step by step, in addition to some theoretical references.

\section{Innovative Learning Environment (ILE)}

The innovative learning environment can be considered a holistic concept. "It embraces both the learning taking place and the setting in which it occurs: an eco-system of learning that includes the activity and outcomes of learning " (OCDE, 2013; De Corte, 2010).

This framework, as shown in Figure 1, contains three components: the pedagogical core (learning leadership and design, evaluation, feedback and redesign), relationships and dynamics (leadership, organizational strategy, partnerships with businesses, cultural institutions) and partnership (connections) (De Corte, 2010).

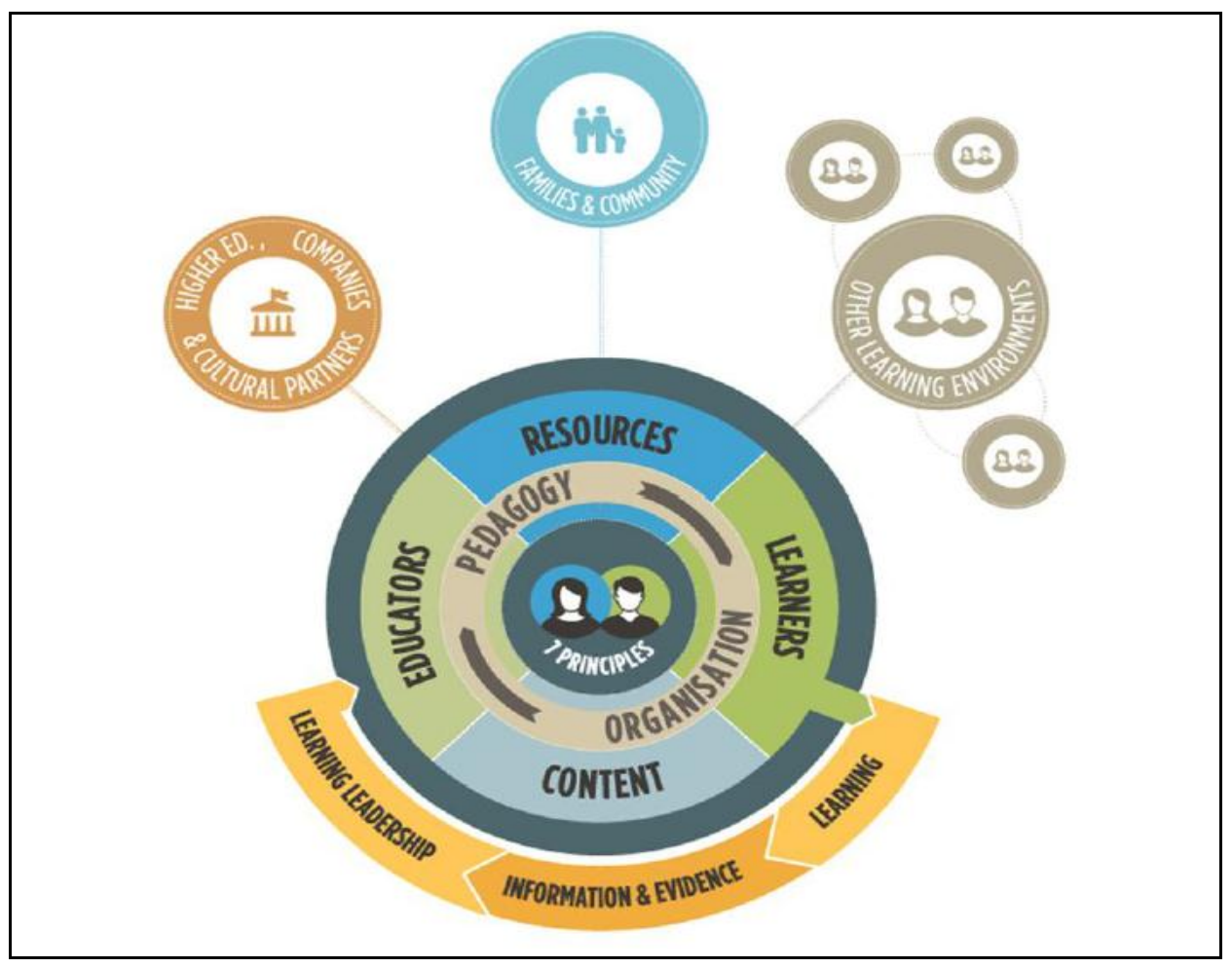

Figure 1. The Innovative Learning Environment framework 
Source: OECD, 2013

ILE follows seven principles for innovative learning:

1. Learners must be at the center of what happens in the classroom

2. Learning is a social practice and cannot happen alone

3. Emotions are an integrative part of learning

4. Learners are different

5. Students need to be stretched, but not too much

6. Assessment should be for learning, not of learning

7. Learning needs to be connected across disciplines

For more details, and with reference to innovativeness as defined here, the academic environment is based on learning through a special content and a relationship between educators and learners. Resources are provided by some partnerships, and indicators facilitate the evaluation of the result of this process of learning.

Returning to innovativeness and the process of innovation, we can suppose that innovation can happen on learning content and/or methods. It can be an output of efforts entertained by educators, considered as a pioneer of innovativeness. They must be innovative as a response to evaluative social needs. The educational sector's role and importance have changed.

We can also suppose that academic innovativeness is behavioral, because it is conducted by educators, who influence learners, (knowledge, reflection and behavior); and technological because of the use of different methods and tools to innovate.

The benefits of such system of innovativeness are multiple for both society and the educational system. For this study, we will only consider the benefits on the educational system.

ILE is important, as it underlines interaction between different levels of the educational system to provide innovativeness. Based on this, learning must be defined as capacities which are developed by individuals according to the context in which they operate.

To understand its effect, we will use the concept of organizational learning capacities (OLC) defined as "organizational and managerial characteristics, practices, skills or factors that facilitates the organizational learning process or allows organizations to learn" (Jerez-Gomez et al., 2005, p.56) and to develop, distribute and use new technologies to innovate (Alegre and Chiva, 2008).

Akgun et al. (2013) argue that OLC stimulate innovation and provide information from outside to develop new products, process and management techniques.

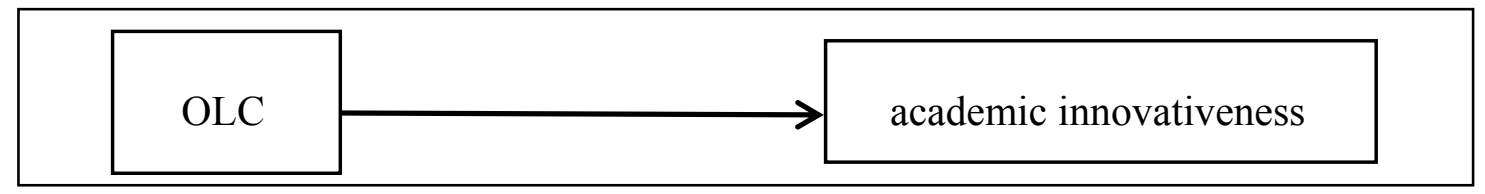

Figure 2. Direct effect of OLC on academic innovativeness 
Like any process of innovation, academic innovativeness can stimulate performance.

Academic performance must be evaluated from the two sides of this process: educators and learners. We considered teaching performance for the first and research performance for the second.

Our framework has the following elements:

\section{a. Antecedents}

Antecedents, or drivers, are factors or stimulators which can highlight a need for innovativeness and trigger its occurrence. These are essential elements for the generation of capacities and competencies able to facilitate innovativeness.

Our literature review show that many factors can contribute to this process. We can find so-called individual factors, such as management and leadership styles that place value on creativity (Burns and Stalker, 1961).

Second, we have organizational factors such as management procedures and resources (Atuahene-Gima and Ko, 2001), firm-specific competencies (Souitaris, 2002), organizational context (e.g., size, age, and resource slack (Nystrom et al., 2002) and networks (Holmen et al., 2004)

The third factor is external organizational context. Here, we can consider an organization's external environment (Calantone and al., 2002), socio-economic and country-specific factors (Souitaris, 2002).

Another approach related to drivers for innovativeness can be detected through the educational system model defined by Johnson (2008). This presents four factors for academic innovativeness: economic, social, political and technological.

Economic factors relate to globalization and the growth of economics. Social factors are represented by special skills. Political factors are adopted and defined national and international policies. Technological factors consist of the use of the new technology (Hennessy and London, 2013).

All of these factors considered as antecedents are represented by OLC. In fact, these capacities can contribute to enhance organizational members' ability to understand information and to recognize new opportunities which can foster new innovations (Martins and Terblanche, 2003)

Additionally, the notion of pragmatic creativity is strongly linked to innovation, it is related to learning organizational culture (Hussein et al., 2016). It involves finding, individually or collectively, solutions which deal with situations and problems. In this sense, it seems that innovation and problem solving are related.

\section{b. Outcomes}

Innovativeness leads to a deliberate effort to improve the function of systems or devices (Develay and Godinet, 2007), and that drives performance based on "core value creating 
capabilities" (Dulger and al., 2016)

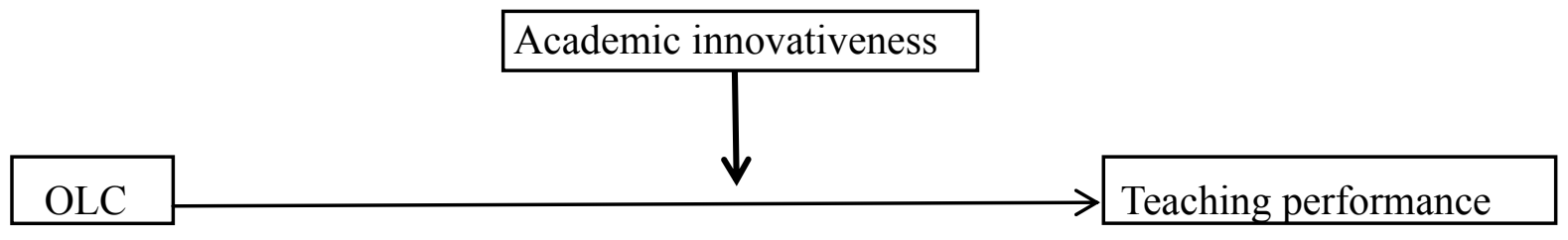

Figure 3. The moderator effect of academic innovativeness

Figure 4 represents the theoretical framework related to this study. All dimensions mentioned will be measured and quantified. This process will be detailed in the second part of this article, where items used will also be defined.

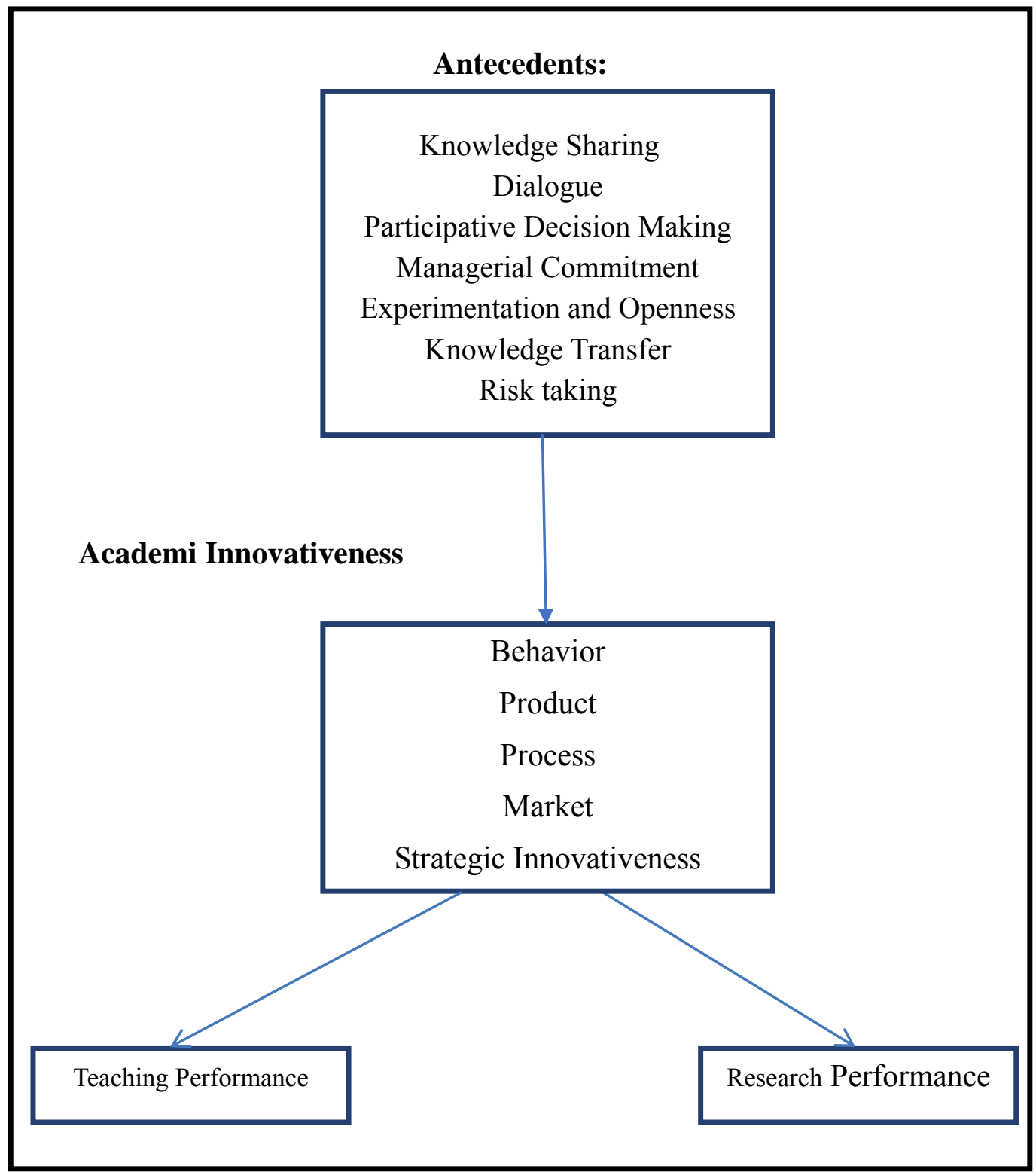

Figure 4. Theoretical framework 


\section{Methodology}

A quantitative approach is adopted here. For the data collection we used a questionnaire distributed to 140 educators in business schools in different area on KSA. All analyses use structural equation modeling by LISREL 8.51 . The response rate was $100 \%$.

Our principal objective is to determine a critical path for academic innovativeness based on organizational learning capability. At the same time, we must demonstrate the role of this innovativeness as a moderator variable between learning capability and teaching performance.

The first step here is thus to determine the dimensions of each concept to facilitate its measure, based on the literature related to our three concepts: organizational learning capacity (OLC), academic innovativeness and performance (teaching and research).

Seven dimensions related to OLC were adopted: items defined by Goh and Richards (1997), Jerez-Gomez et al. (2005) and Chiva et al. (2007).

Twenty items for academic innovativeness are added from Wang and Ahmed (2004), represented by five dimensions.

Academic performance is based on the same scale of job performance presented by Herpen and al. (2003)

All items used are detailed in Table 1.

Table 1. List of items

\begin{tabular}{|c|c|c|c|}
\hline Variables & $\begin{array}{l}\text { Number } \\
\text { of items }\end{array}$ & Alpha & Authors \\
\hline Knowledge Sharing & 8 & \multirow[t]{3}{*}{0.69} & $\begin{array}{l}\text { Goh and Richards (1997), Jerez-Gomez et al. } \\
\text { (2005) and Chiva et al. (2007). }\end{array}$ \\
\hline Dialog & 6 & & $\begin{array}{l}\text { Goh and Richards (1997), Jerez-Gomez et al. } \\
(2005) \text { and Chiva et al. (2007). }\end{array}$ \\
\hline $\begin{array}{l}\text { Participative decision } \\
\text { making }\end{array}$ & 4 & & $\begin{array}{l}\text { Goh and Richards (1997), Jerez-Gomez et al. } \\
(2005) \text { and Chiva et al. (2007). }\end{array}$ \\
\hline $\begin{array}{l}\text { Managerial } \\
\text { commitment }\end{array}$ & 4 & \multirow[t]{4}{*}{0.86} & \multirow[t]{4}{*}{$\begin{array}{l}\text { Goh and Richards (1997), Jerez-Gomez et al. } \\
\text { (2005) and Chiva et al. (2007). }\end{array}$} \\
\hline $\begin{array}{l}\text { Experimentation and } \\
\text { openness }\end{array}$ & 6 & & \\
\hline Knowledge transfer & 3 & & \\
\hline Risk taking & 3 & & \\
\hline Market & 4 & \multirow[t]{5}{*}{0.75} & Wang and Ahmed (2004) \\
\hline Product & 4 & & Wang and Ahmed (2004) \\
\hline Process & 4 & & Wang and Ahmed (2004) \\
\hline Behavioral & 4 & & Wang and Ahmed (2004) \\
\hline Strategic & 4 & & Wang and Ahmed (2004) \\
\hline
\end{tabular}

A structural equations model was used to test our hypothesis. This methodology requires two levels: exploratory and confirmatory. The first stage was carried out by SPSS 16.0 to verify the multidimensionality of constructs, and in the second stage, we used LISREL 8.51 to confirm this composition and its degree of fit. 
Our hypothesis related to the moderating effect of academic innovativeness is now represented by nine hypotheses defined at the different levels of analysis below.

Table 2. Hypothesis of moderating effect

$$
\text { Moderating }
$$

H1. Behavioural innovativeness has a moderating effect on the relationship between knowledge sharing and teaching performance

H2. Behavioural innovativeness has a moderating effect on the relationship between participative decision making and teaching performance

H3. Behavioural innovativeness has a moderating effect on the relationship between risk taking and research performance

H4. Product innovativeness has a moderating effect on the relationship between knowledge transfer and teaching performance

H5. Product innovativeness has a moderating effect on the relationship between knowledge sharing and teaching performance

H6. Process innovativeness has a moderating effect on the relationship between experimentation and openness and research performance

H7. Strategic innovativeness has a moderating effect on the relationship between knowledge sharing and teaching performance

H8. Strategic innovativeness has a moderating effect on the relationship between dialog and teaching performance

H9. Strategic innovativeness has a moderating effect on the relationship between risk taking and teaching performance

H10. Market innovativeness has a moderating effect on the relationship between knowledge sharing and teaching performance

According to Ping (1995), the moderating effect must be treated at six steps after proceeding to the exploratory approach and the confirmatory one.

The confirmatory analysis is established at the first and second level. For each hypothesis, all steps were conducted. The measure model for each variable and its fit was also measured.

\section{Results}

In this part, we summarise the results for each step. First, the multidimensionality of the construct was treated according to the exploratory approach, then we examined the fit of the measure model related to each variable as recommended by Wacheux and Roussel (2001). Finally, the results related to the moderating effect were presented for each hypothesis, and added to the estimation of the multiplication indicator.

Table 3. Exploratory analysis of organizational learning capacity

\begin{tabular}{c|c|c}
\hline \multicolumn{1}{c|}{ Dimension } & Variance & Contribution \\
\hline Individual dimension & 4,862 & $43,51 \%$ \\
Organizational dimension & 1,033 & $8,6 \%$ \\
\hline
\end{tabular}

The results in Table 3 show that the individual dimension of OLC is the most important element, with $43 \%$ of total variance explained. Organizational dimensions contribute to $8 \%$ of total variance. 
The second part of this analysis relates to academic innovativeness and its practices.

Table 4. Exploratory analysis of academic innovativeness

\begin{tabular}{lcc}
\hline \multicolumn{1}{c}{ Dimension } & Variance & Contribution \\
\hline Behavior & 4.55 & $26.77 \%$ \\
Process & 1.74 & $10.23 \%$ \\
Product & 1.37 & $8.10 \%$ \\
Strategic & 1.19 & $7.05 \%$ \\
Market & 1,676 & $13,96 \%$ \\
\hline
\end{tabular}

Table 4 shows that behavior is the most important dimension for innovativeness, meaning that the first step of innovativeness is wanting it, followed by implementing it based on learning and knowledge. We can therefore conclude that innovativeness is a voluntary action which can be translated into a product, process or strategic manner. All of this can affect the market and our position.

Academic innovativeness is thus, at the same time, an objective and a solution which can stimulate teaching and research performance in business schools and then provide the best student quality.

In spite of its presumed importance, training seems to be optional for learning. It explains only $7 \%$ of total variance. This means that training does not strongly influence learning, and team working constitutes a basic element which can define and elaborate organizational learning.

Finally, principal component analysis with varimax rotation was used to determine the composition of organizational innovativeness (Table 5).

Table 5. Exploratory analysis of teaching performance

\begin{tabular}{c|c|c}
\hline Dimension & Variance & Contribution \\
\hline Teaching performance & 7.78 & $35.54 \%$ \\
Research performance & 3.18 & $14.93 \%$ \\
\hline
\end{tabular}

Here, the question was to verify if the items used to measure this variable can be grouped on two axes as defined in the literature review. The analysis yielded two factors, as explained above.

As Table 5 indicates, teaching performance explains $35 \%$ of the variance, while research performance represents $14 \%$ of the total variance.

Performance due to academic innovativeness is represented here by the manner used to communicate and disseminate information to students, added to research performance, which relates to teachers as researchers, able to study and to improve themselves.

The second step for the hypothesis test was the test of fit for each model variable. The results confirm that items adopted after the exploratory approach fit with the principal variable to be measured.

Finally, the hypothesis of the moderating effect of academic innovativeness, as dimensions, on the relationship between organizational learning capacity and teaching performance was tested. 
In this stage, six steps were conducted. Table 6 summarizes the results. The most important step was a determination of the interaction term. Three hypotheses were rejected and two represent a total effect.

Table 6. Results of hypothesis test of mediating effect

\begin{tabular}{c|l}
\hline Result & \multicolumn{1}{c}{ Hypothesis } \\
\hline Rejected & $\begin{array}{l}\text { H1. Behavioral innovativeness has a moderating effect on the relationship between } \\
\text { knowledge sharing and teaching performance }\end{array}$ \\
\hline $\begin{array}{c}\text { Accepted } \\
\text { total effect) }\end{array}$ & $\begin{array}{l}\text { H2. Behavioral innovativeness has a moderating effect on the relationship between } \\
\text { participative decision making and teaching performance }\end{array}$ \\
\hline Accepted & $\begin{array}{l}\text { H3. Behavioral innovativeness has a moderating effect on the relationship between } \\
\text { risk taking and research performance }\end{array}$ \\
\hline Accepted & $\begin{array}{l}\text { H4. Product innovativeness has a moderating effect on the relationship between } \\
\text { knowledge transfer and teaching performance }\end{array}$ \\
\hline $\begin{array}{c}\text { Accepted } \\
\text { total effect) }\end{array}$ & $\begin{array}{l}\text { H5. Product innovativeness has a moderating effect on the relationship between } \\
\text { knowledge sharing and teaching performance }\end{array}$ \\
\hline Rejected & $\begin{array}{l}\text { H6. Process innovativeness has a moderating effect on the relationship between } \\
\text { experimentation and openness and research performance }\end{array}$ \\
\hline Accepted & $\begin{array}{l}\text { H7. Strategic innovativeness has a moderating effect on the relationship between } \\
\text { knowledge sharing and teaching performance }\end{array}$ \\
\hline Accepted & $\begin{array}{l}\text { H8. Strategic innovativeness has a moderating effect on the relationship between } \\
\text { dialog and teaching performance }\end{array}$ \\
\hline Accepted & $\begin{array}{l}\text { H9. Strategic innovativeness has a moderating effect on the relationship between } \\
\text { risk taking and teaching performance }\end{array}$ \\
\hline Rejected & $\begin{array}{l}\text { H10. Market innovativeness has a moderating effect on the relationship between } \\
\text { knowledge sharing and teaching performance }\end{array}$ \\
\hline
\end{tabular}

Behavioral innovativeness has a moderating effect on the relationship between participative decision making and teaching performance. This hypothesis represents a total effect. This means that academic innovativeness in its behavioral dimension stimulates the relationship between participative decision making and teaching performance. In other words, a personal approach of innovativeness facilitates openness and communication with others, which makes the teaching process easier, faster and more efficient.

Product innovativeness has a moderating effect on the relationship between knowledge sharing and teaching performance. We can say that if academic innovativeness as a product is defined and exists as a new way for teaching, this can automatically improve the importance of knowledge sharing and make teaching more interesting and easier.

The last observation based on this research is related to the dimension of process and market. Here the hypotheses related to their effect were rejected, as these two dimensions do not affect this process of teaching performance. As defined at the beginning of this study, this is due to the nature of academic innovativeness, which is an internal and personal process related directly to a voluntary action taken by the institution itself, and this is related to the nature of innovation in service. 


\section{Conclusion}

Like each innovative process, academic innovativeness needs an adequate learning process. It seems important to define an environment in which innovation can take place more easily and quickly.

The innovative learning environment as presented here depends on organizational learning capacity, based especially on knowledge at individual and organizational levels.

The impact of innovation on organizational performance is guaranteed and has been discussed by many researchers. The factor analysis in this study also demonstrates a positive effect of innovativeness on performance. Added to this, the results show the relative importance of organizational learning capacity and confirm that academic performance is affected by innovativeness of teaching performance.

Finally, this study demonstrates that the product and behavioral dimensions of academic innovativeness have a total moderating effect on the relationship between learning and academic performance.

We can conclude that academic innovativeness can be an objective and a stimulator. In the first case, it is a result of another process, and in the second it is an actor.

\section{References}

Akgun, A. E., Ince, H., Imamoglu, S. Z., Keskin, H., \& Kocoglu, I. (2013). The mediator role of learning and business innovativeness between total quality management and financial performance. International Journal of Production Research, 52(3), 888-901. https://doi.org/10.1080/00207543.2013.843796

Alegre, J., \& Chiva, R. (2008). Assessing the impact of organizational learning capability on product innovation performance: an empirical test. Technovation, 38, 315-326. https://doi.org/10.1016/j.technovation.2007.09.003

Atuahene, G. K., \& Ko, A. (2001). An Empirical Investigation of the Effect of Market Orientation and Entrepreneurship Orientation Alignment on Product Innovation, Organization Science, 12(1), 54-74. https://doi.org/10.1287/orsc.12.1.54.10121

Avlonitis, G. J., Kouremenos, A., \& Tzokas, N. (1994). Assessing the Innovativeness of Organizations and its Antecedents: Project Innovstrat, European Journal of Marketing, 28(1), 5-28. https://doi.org/10.1108/03090569410075812

Brewer, D., \& Tierney, W. (2012). "Barriers to innovation in the US education", in Wildavsky, B., Kelly, A. and Carey, K. (Eds), Reinventing Higher Education: The Promise of Innovation (11-40). Cambridge, MA: Harvard Education Press.

Burns, T., \& Stalker, G. M. (1961). The management of innovation. London: Tavistock.

Calantone, R. J., Cavusgil, S. T., \& Zhao, Y. (2002). Learning Orientation, Firm Innovation Capability, and Firm Performance, Industrial Marketing Management, 31, 515-524. https://doi.org/10.1016/S0019-8501(01)00203-6 


\section{Ml Macrothink}

International Journal of Human Resource Studies ISSN 2162-3058 2018, Vol. 8, No. 1

Cerna, L. (2013). The nature of policy change and implementation: a review of different theoretical approaches. OECD/CERI paper.

Charlier, B., \& Peraya, D. (2003). Technologies contemporaines de l'éducation. Dispositifs innovants de formation pour l'enseignement supérieur. Brussels: De Boëck Université.

Chiva, R., Alegre, J., \& Lapiedra, R. (2007). Measuring organizational learning capability among the workforce. International Journal of Manpower, 28(3), 224-242. https://doi.org/10.1108/01437720710755227

Cross, N., \& Cross, A. (1998). Expertise in engineering design. Research in engineering design, 10(30), 141-149. https://doi.org/10.1007/BF01607156

Csikszentmihalyi, M. (2013). Creativity: The Psychology of Discovery and Invention. New York, NY: Harper Perennial.

De Corte, E. (2010). Les conceptions de l'apprentissage au fil du temps, in H. Dumont, D. Istance et F. Benavides (Eds) Comment apprend-on?: La recherche au service de la pratique. France : Éditions OCDE.

Develay, M., \& Godinet, H. (2007). Eléments pour une problématique du changement, in Wallet (Ed) Le Campus Numérique Forse: analyses et témoignages. Rouen: Publications des Universités de Rouen et du Havre.

Dulger, M., Alpay, M. B., Yilmaz, C. (2016). How does learning orientation generate product innovativeness and superior firm performance. The business and management review, 7(3), 208-217.

Ellonen, R., Blomqvist, K., \& Puumalainen, K. (2008). The role of trust in organizational innovativeness, European Journal of Innovation Management, 11(2), 160-181. https://doi.org/10.1108/14601060810869848

Evans, R., \& Leppmann, P. (1970). Resistance to Innovation in Higher Education. San Francisco, CA: Jossey-Bass.

Goh, S., \& Richards, G. (1997). Benchmarking the learning capability of organizations, European Management Journal, 575-583. https://doi.org/10.1016/S0263-2373(97)00036-4

Hennessy, S., \& London, L. (2013). Learning from. International Experiences with Interactive Whiteboards: The Role of Professional Development in Integrating the Technology. OECD Education Working Papers. https://doi.org/10.1787/5k49chbsnmls-en

Herpen, M., Praag, M., \& Cools, K. (2003). The effects of performance measurements and compensation on motivation. Working paper 048/3. Tinbergen Institute Discussion Paper.

Hoffman, A., \& Holzhuter, J. (2012). The evolution of higher education: innovation as natural selection, in Hoffman, A. and Spangehl, S. (Eds), Innovation in Higher Education: Igniting the Spark for Success (3-15), American Council on Education, Lanham, MD: Rowman \& Littlefield. 
Holmen, E., Pedersen, A. C., \& Torvatn, T. (2004). Building relationships for technological innovation. Journal of Business Research, (in press), Elsevier Science Inc. https://doi.org/10.1016/j.burses.2003.10.010

Hult, G. T. M., Hurley, R. F., Knight, G. A. (2004). Innovativeness: Its Antecedents and Impact on Business Performance, Industrial Marketing Management, 33, 429-438. https://doi.org/10.1016/j.indmarman.2003.08.015

Hussein, N., Omara, S., Noordina, F., \& Ishaka, N. A. (2016). Learning Organization Culture, Organizational Performance and Organizational Innovativeness in a Public Institution of Higher Education in Malaysia: A Preliminary Study. Procedia Economics and Finance, 37, 512-519. https://doi.org/10.1016/S2212-5671(16)30159-9

Jerez, G. P., Céspedes, L. J., \& Valle, C. R. (2007). Organizational learning and compensation strategies: Evidence from the Spanish chemical industry. Global Business and Organizational Excellence, 26(3), 51-72. https://doi.org/10.1002/joe.20144

Johnson, E. (2008). Ecological systems and complexity theory: toward an alternative model of accountability in education. Complicity: An International Journal of Complexity and Education, 5(1), 1-10.

Kundu, S. K., \& Katz, J. A. (2003). Born-International SMEs: BI-Level Impacts of Resources and Intentions. Small Business Economics, 20(1), 25-47. https://doi.org/10.1023/A:1020292320170

Lam, W., \& Chua, A. (2005). Knowledge Management Project Abandonment: An Exploratory Examination of Root Causes, Communications of the Association for Information Systems, 16, 723-743.

Lauder, H., Brown, P., Dillabourgh, J. A., \& Halsey, A. H. (eds.) (2006). Education, Globalization and Social Change. Oxford: Oxford University Press.

Liao, S., Wu, C., Hu, D., \& Tsuei, G. A. (2008). Knowledge acquisition, absorptive capacity, and innovation capability: An empirical study of Taiwan's knowledge-intensive industries. World Academy of Science, Engineering and Technology, 160-167.

Manu, F. (1992). Innovation Orientation, Environment and Performance: A Comparison of U.S. and European Markets. Journal of International Business Studies, 23(2), 339-359. https://doi.org/10.1057/palgrave.jibs.8490271

Martins, E. C., \& Terblanche, F. (2003). Building organizational culture that stimulates creativity and innovation. European Journal of Innovation Management Review, 6(10), 64-74. https://doi.org/10.1108/14601060310456337

Nabi, A., Shaprova, G., Buganova, N., Shaushekova, B., Turkenov, T. K. (2017). Methodological aspects of E-Learning innovativeness. Revista ESPACIOS, 38(25):22-33.

Nystrom, P. C., Ramamurthy, K., \& Wilson, A. L. (2002). Organizational context, climate and innovativeness: adoption of imaging technology. Journal of Engineering and Technology 


\section{Macrothink}

International Journal of Human Resource Studies

ISSN 2162-3058

2018, Vol. 8, No. 1

Management, 19(3/4), 221-247. https://doi.org/10.1016/S0923-4748(02)00019-X

OECD. (2005). Oslo Manual. Guidelines for Collecting and Interpreting Innovation Data (3rd Ed). Paris: OECD. https://doi.org/10.1787/9789264013100-en

OECD. (2013). Innovative Learning Environments. Paris: OECD. https://doi.org/10.1787/9789264203488-en

Ping, R. A. Jr. (1995). A parsimonious estimating technique for interaction and quadratic latent variables. The Journal of Marketing Research, 32, 336-347. https://doi.org/10.2307/3151985

Serdyukov, P. (2017). Innovation in education: what works, what doesn't, and what to do about it? Journal of Research in Innovative Teaching \& Learning, 10(1), 4-33.

Souitaris, V. (2002). Firm-specific competencies determining technological innovation: a survey in Greece. R\&D Management, 32(1), 61-77. https://doi.org/10.1111/1467-9310.00239

Vieluf, S., Kaplan, D., Klieme, E., \& Bayer, S. (2012). Teaching Practices and Pedagogical Innovation: Evidence from TALIS [Online] Available: www.oecd.org/edu/school/ TalisCeri\%202012\%20(tppi)-Ebook.pdf (September $15, \quad$ 2017). https://doi.org/10.1787/9789264123540-en

Wacheux, F., \& Roussel, P. (2001). Management des ressources humaines: methodes de recherche en sciences humaines et sociales. Brussels: Deboek.

Wang, C. L., \& Ahmed, P. K. (2004). The development and validation of the organisational innovativeness construct using confirmatory factor analysis. European Journal of Innovation Management, 7(4), 303-313. https://doi.org/10.1108/14601060410565056

Winner, E., Goldstein, T., \& Vincent, L. S. (2013). Art for Art's Sake? The Impact of Arts Education. Paris: OECD. https://doi.org/10.1787/9789264180789-en

\section{Copyright Disclaimer}

Copyright for this article is retained by the author(s), with first publication rights granted to the journal.

This is an open-access article distributed under the terms and conditions of the Creative Commons Attribution license (http://creativecommons.org/licenses/by/4.0/). 